\title{
The Women's Preference for the Management Patterns of Farmland Water Conservation and Their Willing of PIM in Chinese Grain-Producing Areas
}

\author{
Fang Luo ${ }^{1,}$, , Miao Tian ${ }^{1,2}$, Lijun $\mathrm{Chen}^{3}$, Dan Xu', Qing Wang ${ }^{1}$, Yewang Zhou ${ }^{1}$ \\ ${ }^{1}$ School of Commerce, Huanggang Normal University, Huanggang City, China \\ ${ }^{2}$ Economics \& Management College, Zhaoqing University, Zhaoqing City, China \\ ${ }^{3}$ School of Tourism Culture and Geographical Science, Huanggang Normal University, Huanggang City, China \\ Email address: \\ luofang68@163.com (Fang Luo), tianmiaoqq@yahoo.com.cn (Miao Tian), lijunchen1981@tom.com (Lijun Chen) \\ *Corresponding author
}

\section{To cite this article:}

Fang Luo, Miao Tian, Lijun Chen, Dan Xu, Qing Wang, Yewang Zhou. The Women's Preference for the Management Patterns of Farmland Water Conservation and Their Willing of PIM in Chinese Grain-Producing Areas. Agriculture, Forestry and Fisheries.

Vol. 5, No. 3, 2016, pp. 79-86. doi: 10.11648/j.aff.20160503.18

Received: June 23, 2016; Accepted: July 9, 2016; Published: July 12, 2016

\begin{abstract}
The Chinese grain-producing areas undertake the heavy responsibility for the national food security, and the management patterns of farmland water conservation play a decisive role in the grain yield. Women are the main force of agriculture production at most areas. The research from the perspective of female, the vulnerable group has important practical significance. Based on the data of the grain-producing areas, Hubei Province, the multinomial model and the Probit model are applied to analyzing women's preference for the management patterns of the farmland water conservation and their willing of participatory irrigation management (PIM). It turned out that the collective management or the family-mode management solved the irrigation problems of dispersive and finely-divided farmland, the rural elites could decrease the marketization degree of the farmland water conservation, and the male prime rural labors might relieve the pressure of irrigation. Individual pattern of irrigation management is insufficient to ensure the seasonal demands of paddy crops. The rural education, the arable land area and the rural elites' management contribute to enhance the women's willing of PIM, and the male prime rural labor decreases his willing of PIM.
\end{abstract}

Keywords: Grain-Producing Areas, Women, Farmland Water Conservation, Participatory Irrigation Management, Management Patterns

\section{Introduction}

The Chinese grain-producing areas undertake the heavy responsibility for the national food security. To achieve the goal of the food production is dependent on the development level of the farmland water conservation. In People's Commune period and at the beginning of allocating plots of land to households, due to the massive investment of the farmland water conservation and the community management, the water conservation development level of the grain-producing areas is enough to ensure stable yields in the face of drought or excessive rain. However, after entering the mid and late 1990s, especially since the rural tax-fee reform in 2001, the farmland irrigation has been in a dilemma. The original large- and medium-sized water conservation facilities are damaged and even abandoned due to lack of management and maintenance. The collective management pattern of the farmland water conservation eventually transforms into market-oriented or family-oriented pattern.

At present, the academics have four opinions on management patterns of the farmland water conservation: (i) Collectivization. The village collectives supply the farmland water conservation facilities whose management right is controlled by the village cadres. The village cadres exercise the powers of occupation, usage and dominion over small scale water conservation facilities. The collectivization of the 
water conservation has scale benefit, which may decrease the cost of water used and ensure stable yields in the face of drought or excessive rain [1]. To come into play with the community-managed irrigation systems, the water users should take control of and carry out multiple tasks, including regulations establishment and enforcement, water distribution, hydraulic works operation, infrastructures maintenance, resources mobilization and administration, and alliance building and networking [2]. The collective irrigation can completely meet the crop water demand, but its efficiency in exploiting the water resources is very low. The Water Users' Associations (WUAs) take part in the collective irrigation service, but the ability of financial self-sufficiency is at low level. Among various WUAs, the costs of management, maintenance and operation, and the individual requirements are different. The average water prices are varied in a very wide range in different regions [3]. The community-managed irrigation systems are commonly faced with problems of low system-level performance. The main cause was inappropriate farmers' practices at field level where the irrigation duration was almost twice the expected, which were associated with farmers' poor commitment to irrigation management, small farms and excessive land division, the expensive supply of sand, and the specific case of uncontrolled night irrigation events [4]. (ii) Marketization. The inflow of private capitals offsets the insufficient government investment and farmer themselves investment [5]. The ownership of water conservation belongs to the state while the rights of usage, management and operation are transferred to the independent subject of market economy, which adopts the pattern of enterprise-like management to provide paid irrigation service to the farmers [6]. The farmland irrigation includes two market-oriented patterns: the market producing and offering, and the market producing and the government offering [7]. This marketization is classified into three types: various levels' contract system, government subsidizing and private running system, and projects system [8]. The water trading is better viewed as part of a social contract which results in a spatially-efficient allocation of water [9]. Privately managed irrigation schemes have proven their ability to achieve high performance in arid and semi-arid regions [4]. With the market supplying, bringing the market into full play and limiting the private benefit over-expansion are the main issues of the government supervision [7]. (iii) Family-oriented pattern. In rural China, the peasant households are extremely dispersed. Even if there are common water wells and towers, which are abandoned, because the villagers can't reach an agreement on issues such as the electric charge of pumping and so on. In these decentralized villages, the peasants are used to independent operation without cooperation [10]. In the context of the taxes and fees reform, the rural governance resources of the village cadres drain, and there is no internal binding among the villagers [11]. Hence, the peasant households independently solve the problems of drought, provided that the water conservation facilities don't exist externality to some extent and the land stretches vastly [10]. The villagers have three uncooperative patterns to cope with drought: proxies, digging wells, and trenching [11]. However, these kinds of small scale water conservation facilities only work in years of good rains shielded, but they can't fight against drought really [10]. Pakistan was undergoing institutional reforms to implement participatory irrigation management (PIM) with the involvement of farmers' organization (FO). Based on the estimated parameters such as delivery performance ratio (DPR), spatial coefficient of variation (CVS), temporal coefficient of variation (CVT), farmers' net income, and land and water productivities, it is concluded that the overall performance of FO-managed irrigation canal was better than the state-managed canal [12]. (iv) The others. For example, some researchers suggest that the village collective, WUAs and farmers jointly undertake the management and maintenance of the farmland water conservation.

The existing studies seldom focus on the willing of the female PIM [13]. For instance, Guo et al. shown that the willing of the female PIM was positively related to education, physical condition, attitude of family member and psychological quality, and negatively related to age and household size [14]. So far, the scholars haven't paid attentions to the issue of female preference for the management patterns of farmland water conservation. From a female perspective, the management patterns selection of the farmland water conservation is tested in major grain-producing areas, and then the willing of female PIM is further explored. The reason of selecting the special group, females as research object is that they are both social vulnerable group and present dominant force of agricultural production [15]. With the pace of urbanization accelerating in China, it is popular that the peasant-workers locally transfer and have the jobs closer to home. The women have to look after the elderly and children. They undertake agricultural production that is a kind of time flexible and stable work, which is a rational choice to allocate labor resources of peasant households. The analysis of the characteristics of the female production behavior helps to understand the stage feature of Chinese agriculture transitional development, and has practical guide significance for the related agricultural policy made. In the next section, we introduce data source and report descriptive statistics, select variables and models, and analyze the regression results. Finally, the important conclusions are drawn and their policy implications are given.

\section{Data Sources and Its Descriptive Statistics}

The data of rural women and farmland irrigation management were gathered in September and October 2015, which covered more than ten cities in Hubei Province, such as Wuhan, Huangshi, Huanggang, Ezhou, Jingmen, and so on. Of the 300 questionnaires sent out, totally 279 effective questionnaires were retrieved, whose effective rate was up to $93 \%$. 
The survey data of Hubei Province shows that the present age structure of the women involved in agricultural production is not reasonable in major grain-producing areas. The proportion of the old, the middle-aged and the young is $1: 2: 1$ that shows that the young ratio is low ${ }^{1}$. The average age of female labors is 47 years old that indicates an aging tendency. The women's education level is low. The percentages of primary school or below, junior high school, and high school or above are $56.6 \%, 29.7 \%$ and $13.6 \%$, respectively. Their health is general. The percentages of very health, general health, and out of condition are $31.2 \%, 40.1 \%$ and $28.7 \%$, respectively. Their children are mostly adult due to the aging tendency of female labor. The women with children below seven years old account for $3.9 \%$, and the women with children aged 8-15 account for $19.0 \%$. The peasant households averagely have 0.6 male prime labor full-time working on the land, namely, less than 1 . This reflects the feminine feature of the rural labors. Each peasant household averagely has about $0.35 \mathrm{hm}^{2}$ arable land. The ratio of dry land to rice paddy is $1: 1.2$. The major grain-producing areas assume responsibility in the national food security while the agrarian area is seriously insufficient. The peasant household average annual income is $31,000 \mathrm{RMB}$, of which $8,000 \mathrm{RMB}$ from agriculture, accounting for $25.8 \%$ of the total income. This shows that the farmers' income and the agricultural comparative gains are low. The farmland irrigation almost has no difficulty, because Hubei, "the province of thousands of lakes", has unique advantages of natural environment, and recently the state increases investment in the farmland water conservation that releases the policy dividend. The efficiency of the farmland irrigation management is low and the capacity of the managers is insufficient. Only $10.4 \%$ respondents report local civil irrigation organizations established such as WUAs, the $63.8 \%$ respondents report no such kind of organizations established, and $25.8 \%$ respondents have no idea. This sufficiently proves that these civil organizations are irresponsible for organizing the farmers' collective behavior. The females claiming the farmland water conservation marketization, village collective management, domestication and others are $49.1 \%, 25.8 \%, 12.9 \%$ and $12.2 \%$, respectively. It shows that the advantage of marketization in closing the funding gap and raising operation efficiency is recognized by the farmers. The ratio of the willing PIM females to the unwilling females is 3:1. Most major workforce of agricultural production, namely, the females are willing to improve water use efficiency and decrease production cost through PIM. The questionnaire designs multiple-choice question for the female preference for PIM patterns. Among all 279 respondents, the $45.2 \%$ express their willing to give advice on the construction of the farmland water conservation and facilities maintenance, the $39.4 \%$ respondents are willing to invest with their labor in the construction, the $39.4 \%$ respondents like to make a

1 According to 2010's criterion of the World Health Organization (WHO), below 44 years old is youth, aged $45-59$ is the middle-aged and over 60 years old is the elderly. suggestion on water rate charging and price scheme designed, the $32.6 \%$ like to supervise village work of farmland water conservation, and the $26.2 \%$ are willing to provide the money. It shows that the female preferring participatory pattern is giving advice on farmland water conservation, the next is investing with their labor, the third is supervising, and the last is providing the money.

\section{The Variables and Models Selection}

We are going to analyze two problems about the major grain-producing areas female: (i) the management pattern preference of farmland water conservation $\left(Y_{l}\right)$; and (ii) the willing of PIM $\left(Y_{2}\right)$. The determinants of $Y_{1}$ and $Y_{2}$ are analyzed in four aspects: individual characteristics, household characteristics, productive characteristics and village characteristics, denoted by model 1 and model 2, respectively. The individual characteristics variables include female age $(A G E)$, education $(E D U)$ and health condition $(H L T H)$. The household characteristics variables include having underage children $(C H L D)$, prime rural labors full-time working on the land $(P R L)$ and family income $(F M I N)$. The productive characteristics variables include actual cultivated area $(C L A R)$, rice paddy area $(R P A)$ and agricultural income $(A G I N)$. The village characteristics variables include difficulty level of village irrigation $(D L V R)$, whether there being able-person managing irrigation (APMI) and whether local WUAs established (WUA). Except the variable $W U A$ only appearing in model 2, the other variables all appear in both model 1 and model 2.

The statistic software, Stata 14.0 is adopted for regression analysis. Firstly, the female preference for the management pattern of farmland water conservation $\left(Y_{I}\right)$ is analyzed. The surveyed women should answer this question, "you reckon who should manage village farmland water conservation", provided four options for single choice: (a) the Village Party Branch or Committee, (b) contractor, (c) farmer, and (d) the others. Assume that $Y_{I}$ taking 1,2,3 or 4 represents selecting a, $\mathrm{b}, \mathrm{c}$ or $\mathrm{d}$, respectively. This indicates the female preference for the management pattern of village collective, marketization, domestication or the others, respectively. Because the value of $Y_{I}$ is discretely multivalued and unordered selection, the multinomial model is adopted. The base category is "the others". While $Y_{1}$ regresses on the four types of characteristics variables, the $\mathrm{LR} \operatorname{chi}^{2}(33)$ is equal to 41.63 , and its probability, $\operatorname{Prob}\left(>c h i^{2}\right)$ is equal to 0.14 . The overall regression modeling is invalid. Hence, we try to remove the redundant variables or supplement probable missing variables. The ultimate effective model is as follows:

$$
\begin{aligned}
Y_{I i}= & \alpha_{0}+\alpha_{1} P R L_{i}+\alpha_{2} C L A R_{i}+\alpha_{3} R P A_{i}+\alpha_{4} F{ } N_{i} \\
& +\alpha_{5} A G I N_{i}+\alpha_{6} D L V R_{i}+\alpha_{7} A P M I_{i}+\mu_{i},
\end{aligned}
$$

where subscript $i$ represents an observation; $\alpha_{j}(j=0,1, \cdots, 7)$ are parameters to be estimated; $P R L$ is the number of prime rural labors with the full-time working on the land; CLAR is the actual cultivated area, using $100 \mathrm{~m}^{2}$ as a unit due to the 
investigated household average area only $0.35 \mathrm{hm}^{2}$, approximately $3500 \mathrm{~m}^{2} ; R P A$ is the rice paddy area in unit of $100 \mathrm{~m}^{2} ;$ FMIN is the family annual income, and $A G I N$ is the agricultural annual income, adopting the average annual income of recent three years in unit of 10,000 RMB; DLVR is the difficulty level of village irrigation, discrete variable, using rating scale, 1, 2 or 3 represents no problem, almost no problem or having problem, respectively; $A P M I$ is whether there being rural able-persons managing irrigation, dummy variable, taking 1 for having able-person, otherwise $0 ; \mu$ is the error term.

Secondly, the female PIM willing $\left(Y_{2}\right)$ is analyzed. The surveyed women should answer this question, "whether you are willing to partake in farmland water conservation management", provided two options for single choice: (a) I am willing to, and (b) I am not willing to. Assume $Y_{2}$ take 1 for willing, otherwise 0 . Due to the binary value of $Y_{2}$, Probit, the binary selection model with the base category "unwilling" is used. While $Y_{2}$ regresses on the four types of characteristics variables, namely, individual characteristics, household characteristics, productive characteristics and village characteristics, the Wald $\operatorname{chi}^{2}(12)$ is equal to 25.08 , and the probability, Prob $\left(>c h i^{2}\right)$ is equal to 0.0144 . The overall regression modeling is valid. However, among twelve explanatory variables, only three variables are significant. To improve regression effect, we try to remove redundant variables. The ultimate model is as follows:

$$
\begin{aligned}
Y_{2 i} & =\beta_{0}+\beta_{1} E D U_{i}+\beta_{2} H_{L T H}+\beta_{3} C H L D_{i}+\beta_{4} P R L_{i} \\
& +\beta_{5} C L A R_{i}+\beta_{6} R P A_{i}+\beta_{7} F M I N_{i}+\beta_{8} A G I N_{i} \\
& +\beta_{9} D L V R_{i}+\beta_{10} A P M I_{i}+\beta_{11} W U A_{i}+\varepsilon_{i},
\end{aligned}
$$

where $\beta_{j}(j=0,1, \cdots, 11)$ are parameters to be estimated; $E D U$ is female education level that is divided into five levels: illiteracy, primary school, junior high school, senior high school (including various vocational schools), and junior college and above, orderly assigned 1, 2, 3, 4, and 5 in them; HLTH is health condition that is divided into three levels: unhealthy, healthy, and pretty healthy, orderly assigned 1, 2, and 3 in them; CHLD is whether there being underage children, taking 1 for having, otherwise $0 ; W U A$ is whether local WUAs established, taking 1 for established, otherwise $0 ; \varepsilon$ is the error term; the other symbol descriptions see above.

\section{Regression Results Analyzing}

We discuss the regression results of model 1 and model 2 in the section below.

\subsection{The Women's Preference for Management Patterns of Farmland Water Conservation}

The regression results of Equation (1), multivalued selection model (i.e. multinomial logit model) see Table 1. The LR $\operatorname{chi}^{2}(21)$ of the regression is equal to 33.15 , and the probability, $\operatorname{Prob}\left(>c h i^{2}\right)$ is $4.46 \%$. The model is significant at the significance level of $5 \%$, so the overall regression modeling is valid. Because the dependent variable of the multivalued selection model is discrete, through the symbol of the estimated coefficient, the effect direction of explanatory variable on the dependent variable is judged, which does not show the marginal effect. Hence, the software of Stata 14.0 is used further to obtain the odds ratio or the Relative Risk Ratio (RRR) of Equation (1) (see Table 1). The RRR is simply summarized as the ratio of an event occurring to non-occurring. Taking the natural log of RRR is equal to the

\begin{tabular}{|c|c|c|c|c|c|c|c|c|c|c|}
\hline Variable & Coef. & Std. err. & $z$ & $\mathbf{P}>|z|$ & $\mathbf{R R R}^{\star}$ & Coef. & Std. err. & $z$ & $\mathrm{P}>|z|$ & $\mathbf{R R}^{*}$ \\
\hline & \multicolumn{5}{|l|}{ Option $1^{\dagger}$} & \multicolumn{5}{|l|}{ Option $2^{\dagger}$} \\
\hline $\mathrm{C}$ & 1.415 & 1.1391 & 1.2422 & 0.2142 & 4.1163 & $2.3826^{* * *}$ & 1.0557 & 2.2568 & 0.024 & 10.8326 \\
\hline$P R L$ & $-0.8515^{* * *}$ & 0.3661 & -2.3257 & 0.02 & 0.4268 & $-0.6802^{* * *}$ & 0.3235 & -2.1025 & 0.0355 & 0.5065 \\
\hline$C L A R$ & $0.0331^{*}$ & 0.0207 & 1.5946 & 0.1108 & 1.0336 & 0.0227 & 0.0203 & 1.1195 & 0.2629 & 1.0229 \\
\hline$R P A$ & $-0.0401^{* *}$ & 0.0226 & -1.7746 & 0.076 & 0.9607 & $-0.0392^{* *}$ & 0.0227 & -1.7284 & 0.0839 & 0.9616 \\
\hline FMIN & $-0.3711^{* * *}$ & 0.1641 & -2.2612 & 0.0237 & 0.69 & -0.1382 & 0.1266 & -1.092 & 0.2748 & 0.8709 \\
\hline$A G I N$ & $0.5991^{* *}$ & 0.3304 & 1.8133 & 0.0698 & 1.8205 & $0.5210^{* *}$ & 0.3036 & 1.7163 & 0.0861 & 1.6837 \\
\hline$D L V R$ & -0.2812 & 0.4074 & -0.6904 & 0.4899 & 0.7548 & -0.3374 & 0.3757 & -0.8979 & 0.3692 & 0.7136 \\
\hline \multirow[t]{2}{*}{$A P M I$} & 0.2849 & 0.46 & 0.6195 & 0.5356 & 1.33 & $-0.6443^{*}$ & 0.4363 & -1.4767 & 0.1398 & 0.525 \\
\hline & \multicolumn{5}{|l|}{ Option $3^{\dagger}$} & \multicolumn{5}{|c|}{ Option $4^{\dagger}$} \\
\hline $\mathrm{C}$ & -0.1597 & 1.2993 & -0.1229 & 0.9022 & 0.8524 & (base categ & & & & \\
\hline$P R L$ & -0.4551 & 0.4009 & -1.1354 & 0.2562 & 0.6344 & & & & & \\
\hline$C L A R$ & $0.0372^{* *}$ & 0.0213 & 1.7472 & 0.0806 & 1.0379 & \multicolumn{2}{|l|}{ No. obs } & 279 & & \\
\hline$R P A$ & $-0.0414^{* *}$ & 0.0233 & -1.7804 & 0.075 & 0.9594 & \multicolumn{2}{|l|}{$\operatorname{LR} c h i^{2}(21)$} & $33.15^{* * *}$ & & \\
\hline FMIN & 0.0145 & 0.1495 & 0.0971 & 0.9226 & 1.0146 & \multicolumn{2}{|l|}{ Prob $>c h i^{2}$} & 0.0446 & & \\
\hline$A G I N$ & 0.1547 & 0.3716 & 0.4163 & 0.6772 & 1.1673 & \multicolumn{2}{|c|}{ Log likelihood } & -323.675 & & \\
\hline$D L V R$ & -0.048 & 0.464 & -0.1035 & 0.9175 & 0.9531 & \multicolumn{2}{|l|}{ Pseudo $\mathrm{R}^{2}$} & 0.0487 & & \\
\hline$A P M I$ & -0.1642 & 0.5324 & -0.3083 & 0.7578 & 0.8486 & & & & & \\
\hline
\end{tabular}
estimated coefficients.

Table 1. Regression results of the multivalued selection model.

Notes: ${ }^{* * *},{ }^{* * *}$ and ${ }^{* * * *}$ denote being significant at significance level of $15 \%, 10 \%, 5 \%$ and $1 \%$, respectively; ${ }^{\dagger}$ Option $1-4$ represent the women's preference for the management patterns of farmland water conservation, namely, collectivization, marketization, domestication and the others, denoted as " 1 ", " 2 ", " 3 " and " 4 ", respectively. ${ }^{\ddagger}$ The RRR of Option 1-3 are denoted as $R_{R R}, R_{2} R_{2}$ and $R_{R R}$, respectively.

Table 1 shows that the number of prime rural labors full-time working on the land $(P R L)$ is significant in
"1"- collectivization and " 2 "-marketization of farmland water conservation, both negative sign. $\mathrm{RRR}_{1}$, the probability 
ratio of the women's preference for village collective management of farmland water conservation to that for the base category "the others" is $0.4268 . R_{2}$, the probability ratio of women's preference for marketization of farmland water conservation to that for the base category is 0.5065 . PRL is non-significant in " 3 "- - domestication. With the number of prime rural labors full-time working on the land in the family, the women's preference for collectivization and marketization of farmland water conservation decreases, which shows prime rural labors are beneficial to relieve the pressure of irrigation. The actual cultivated area $(C L A R)$ is significant in " 1 "- collectivization and " 3 "- - domestication, both positive sign. The $\mathrm{RRR}_{1}$ of $C L A R$ is $1.0336 . \mathrm{RRR}_{3}$, the probability ratio of the women's preference for domestication of farmland water conservation to that for the base category is 1.0379 . CLAR is non-significant in " 2 ", marketization. With the actual cultivated area increasing, the women's preference for collectivization and domestication of farmland water conservation increases. Because average cultivated area of peasant household is small, and almost half cultivated land is dry land, less demanding for irrigation, collectivization or domestication can meet the need of irrigation in Hubei Province. The rice paddy area $(R P A)$ is significant in " 1 "-collectivization, " 2 "-marketization and “3”- domestication, all negative sign. RPA's $\mathrm{RRR}_{1}$ is 0.9607 , $\mathrm{RRR}_{, 2}$ is 0.9616 , and $\mathrm{RRR}_{3}$ is 0.9594 . The bigger the rice paddy area is, the less the women's preference for collectivization, marketization and domestication of farmland water conservation is. The bigger the rice paddy area is, the stronger its dependency upon irrigation facilities is. The women reckon one of the above three management patterns alone is not enough to meet the accumulated irrigation demand of the seasonal production of paddy crop. They select the other pattern, which includes not only the other individual irrigation patterns, but also two or three pattern compounds of collectivization, marketization and domestication. The family annual income $(F M I N)$ is only significant in " 1 ", collectivization, negative sign, and its $\mathrm{RRR}_{1}$ is 0.6900 . The higher the family annual income is, the lower the women's preference for village collective managing farmland irrigation is. This shows peasant households with higher income have abundant nonagricultural income, not dependent on agriculture for their livelihoods. Hence, their demand for farmland water conservation decreasing results in their preference for collectivization decreased. The agricultural annual income $(A G I N)$ is significant in " 1 "- collectivization and " 2 "- marketization, both positive sign. $A G I N$ 's $\mathrm{RRR}_{1}$ is 1.8205 and $\mathrm{RRR}_{2}$ is 1.6837 . The higher the agricultural income of peasant household is, the stronger their dependency on irrigation is. So their need for collectivization and marketization is more urgent. The difficulty level of village irrigation $(D L V R)$ is non-significant. Because there is little difficult in the farmland irrigation in Hubei Province, the variability of this variable is low. Whether there being rural able-persons managing irrigation $(A P M I)$ is only significant in " 2 "- marketization, negative sign. $A P M I$ 's $\mathrm{RRR}_{2}$ is 0.5250 . If there are rural able-persons, such as rural elites, and members of the Village Party Branch and Village Committee, who are courageous and responsible, the demand of the women for the marketization decreases naturally.

\subsection{The Willing of Women Taking Part in Management of Farmland Water Conservation}

Firstly, the heteroscedasticity of the Probit model of the regression Equation (2) is tested. The statistic value $\operatorname{chi}^{2}(11)$ of likelihood-ratio test of $\ln \sigma^{2}=0$ is 19.67 , and its probability, $\operatorname{Prob}\left(>c h i^{2}\right)$ is 0.0501 . Hence, the null hypothesis of homoscedasticity is rejected at the significant level of $5 \%$. To correct the heteroscedasticity, Robust regression is used and its results see Table 2. The Wald $c h i^{2}(11)$ of the regression is equal to 25.00 , and its probability, $\operatorname{Prob}\left(>c h i^{2}\right)$ is $0.91 \%$. The model is significant at the significance level of $1 \%$, so the overall regression modeling is valid. Because the dependent variable $Y_{2}$ is dummy variable, the estimated coefficients aren't the marginal effects of explanatory variables on dependent variable, their signs only showing the effect direction. Hence, it is necessary to consider the marginal effects further. The marginal effects of explanatory variables obtained through Stata 14.0 see Table 2.

Table 2. The regression results and the marginal effects of the Probit model.

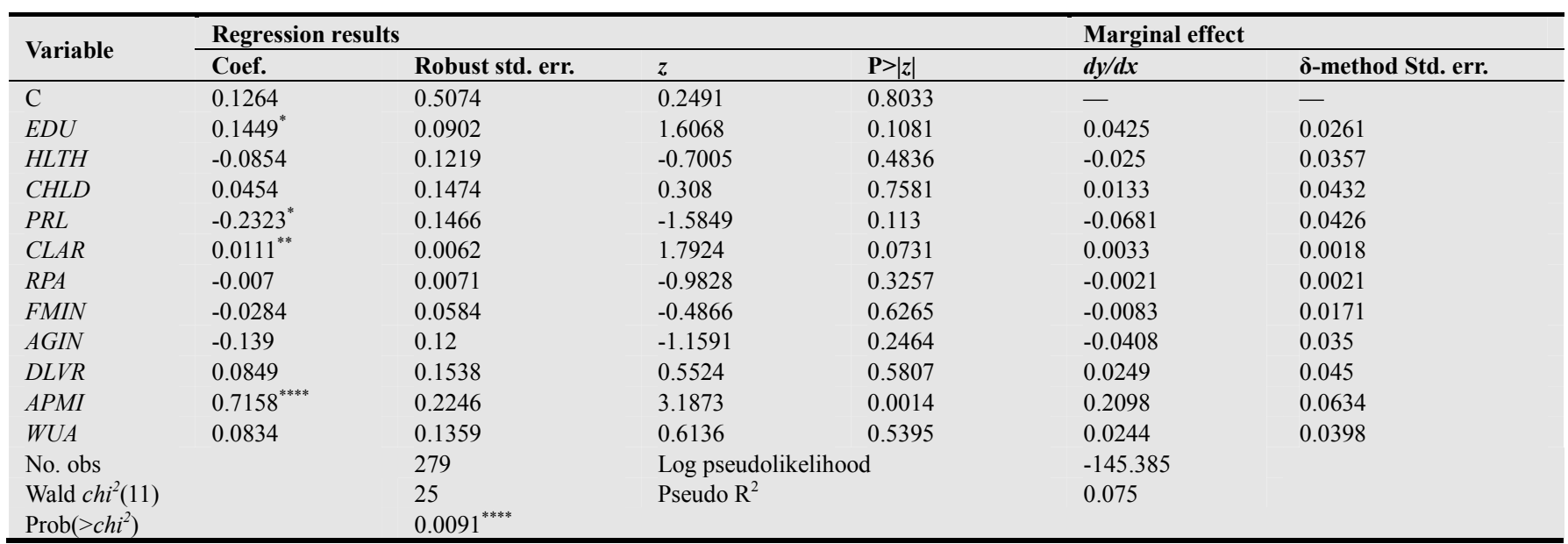

Notes: ${ }^{*},{ }^{* *},{ }^{* * *}$ and ${ }^{* * * *}$ denote being significant at significance level of $15 \%, 10 \%, 5 \%$ and $1 \%$, respectively. 
As listed in table 2, the women's education level (EDU) is significant at significance level of $15 \%$, positive sign. The women's education level upgrades a degree, for example, from the primary school to the junior high school, or from the junior high school to the senior high school, which results in the probability of the women's willing to take part in the management of farmland water conservation averagely increasing $4.25 \%$. This shows rural education broadens women's vision and open their mind that makes them like to participate in collective actions. The number of prime rural labors full-time working on the land $(P R L)$ is significant at the significance level of $15 \%$, negative sign. With $P R L$ increasing 1 , the probability of women's willing to take part in the management of farmland water conservation averagely decrease $6.81 \%$. The rural women still keep the traditional thought, "women's domestic and men's more public roles". To consider family division-cooperation, the male prime labors take up the heavy responsibility of family agricultural production, and they are naturally responsible for the farmland irrigation. The women spend most time and energy in doing housework and looking after the elderly and children. And then they become secondary labors of agricultural production, namely production assistants, so their willing of PIM decreases. The actual cultivated area $(C L A R)$ is significant at the significance level of $10 \%$, positive sign. With CLAR increasing 1 unit, i.e. $100 \mathrm{~m}^{2}$, the probability of the women willing to participate in the farmland water conservation averagely increases $0.33 \%$. This shows that the more the cultivated area is, the bigger the demand for irrigation is. So the women are more willing to participate in irrigation management. Whether there being rural able-persons managing irrigation $(A P M I)$ is significant at the significance level of $1 \%$, positive sign. While there are able-persons managing farmland irrigation in the village, the probability of the women's willing to participate in management increases $20.98 \%$. The reason is that the rural able-persons are generally elites such as members of Village Party Branch and Village Committee, who can raise work efficiency and decrease the costs of management, maintenance and operation of farmland water conservation. The women believe them that motivates the women PIM. The women's health condition (HLTH) doesn't significantly affect the participatory willing. Their health condition is a "double-edged sword" for the farmland irrigation management. On the one hand the good health makes the women have the energy to take part in the farm water management. On the other hand, it makes it possible to irrigate individually and not to participate in collective actions. Hence, these two strengths cancel each other out that makes the variable $H L T H$ non-significant. Whether there being underage children $(C H L D)$ is non-significant. There being underage children makes women have no time and energy to participate in the irrigation management. However, in Hubei Province, the women involved in agricultural work are most in their middle and old age, averagely 47 years old. Their children are adults. They have time to participate in the irrigation management or have energy to irrigate themselves.
These two strengths cancel each other out that makes the variable $C H L D$ non-significant. The rice paddy area $(R P A)$ is non-significant. The rice paddies strongly rely on irrigation, so the bigger area must be beneficial to promote women PIM. However, the average peasant households' rice paddy area is too small (only $0.19 \mathrm{hm}^{2}$ ) to promote the willing of women PIM. The family annual income (FMIN) is non-significant. Due to the low agricultural comparative benefit, the higher the family income is, the more the non-agriculture income is. So the agriculture income is less. The peasant households attach less weight to agriculture, and then the willing of women PIM decreases. However, Hubei Province is less developed region in the central of China, and the income of most peasant households is not high enough to ignore agricultural production, therefore the variable FMIN is non-significant. The agricultural annual income $(A G I N)$ is non-significant. The agricultural income may come from the grain crops that requires more water or cash crops that requires less water. With the agricultural income increasing, the proportion of the cash crops rises, which gets the water demand down. In the meantime, the absolute amount of cash crops rises, which promotes the water demand. Hence, the change of the ultimate water demand is not significant which makes the willing of women PIM not significantly change. The difficulty level of village irrigation $(D L V R)$ is non-significant. While the village irrigation has trouble, the women don't reckon they can resolve the problems through themselves PIM, so the willing of women PIM decreases. While the village irrigation doesn't have trouble, the women think it isn't necessary to take part in management, so the willing of women PIM decreases. On the whole, whether the irrigation has trouble or not, the women's willing decreases which results in the variable $D L V R$ non-significant. Whether WUAs established (WUA) in the village is non-significant. The WUAs are the effective organization of farmer PIM. There are only $10.4 \%$ villages established these associations in Hubei Province, and generally the male head of the household is the member of the associations, hence the effect of the WUAs established on the willing of women PIM is non-significant.

\section{The Important Conclusions and Their Policy Implications}

To sum up, it is not too hard to draw the important conclusions as follows.

Firstly, the women's preference for the management patterns of farmland water conservation. Collectivization or domestication can resolve the irrigation problems of small cultivated area and scattered farmland. If there are rural elites such as the members of the Village Party Branch and Village Committee, and so on, who operate and manage the farmland water conservation facilities, the propensity to marketization decreases. The male prime labors may relieve the pressure of the farmland water conservation. One of the three management patterns, namely collectivization, marketization 
and domestication alone is not enough to meet the accumulated irrigation demand of the seasonal production of paddy crops. It is necessary that their compounds may cope with the abrupt changes of demand without rushing, especially in the period of extreme climate prone. The peasant households' demand for irrigation increases with the agricultural income, and decreases with the family income, because the proportion of non-agricultural income of the peasant households with high income is larger, and their dependency on the agricultural production decreases.

Secondly, the willing of women PIM. The rural education helps to promote the willing of women PIM. With the number of prime rural labors full-time working on the land rising, the willing of women PIM decreases. From the family division-cooperation point of view, this is a method of promoting family resources allocation efficiency. The more the actual cultivated area is, the stronger the willing of women PIM is. The rural elites such as the members of the Village Party Branch and Village Committee, and so on, who operate and manage the facilities of farmland water conservation, promote the willing of women PIM.

Based on the above conclusions, we may advance policy implications as follows.

Firstly, the organization cost sharing pattern of the union of collective, market and peasant household should be established. The benefit covering ranges of various water conservation facilities are different. The individual irrigation managing pattern can't cope with the farmland water conservation problems of different levels. For example, the reservoirs may engage concurrently in fish breeding, which has the ability of self-maintenance to some extent, hence it can be market operation. However, the pump stations can only obtain revenues from pumping, so it can't be market operation and should be managed by the water conservation department of the towns or counties. The pump stations with irrigation area over $10,000 \mathrm{Mu}$, approximately $666.7 \mathrm{hm}^{2}$, can be determined to be quasi-public welfare unit. The Chinese government may set up a special fund of management and maintenance to pay for the wages of the workers and daily maintenance expenditures of the pump stations. This special fund can come from the "two subsidies", namely, granted direct subsidy to grain producers and the comprehensive agricultural subsidy. Presently, the "two subsidies" are directly provided for the peasant households. Although they get some benefits, the capital usage efficiency is very low. Because of non-timely or costly irrigation, the loss of the peasant households is larger than the benefits getting from "two subsidies". If part "two subsidies" funds are directly transferred to the pump stations, it may play a well-leveraged role, which will raise the capital usage efficiency greatly [16].

Secondly, the all-around three-dimensional rural women education network should be established. The education of rural women should be developed and have its own characteristic through checking its leakage and filling its vacancy. First, the idle resources of the rural education should be mobilized and the community training should play a dominant role. Training women in the rural community may save time and decrease the cost of attend training. With the urbanization pushed forward, the rural students transfer to the urban schools, and the student resources of lots of rural schools decrease or even exhaust. This results in the rural standard nine year-compulsory education facilities equipped by the government remaining idle. If these idle resources including rural teachers can be applied to the rural women training, a few parties will be benefited. Second, the adult colleges realize their gorgeous turning around through establishing the rural women education platform. With the Chinese higher education popularizing, most adult colleges make a transition to general higher schools. The rest adult colleges should take advantage of having lots of faculty who are familiar with the grass roots level, especially the countryside, seize the opportunities of the government attaching great importance to the adult education, establish the rural women education platforms that have their own characteristic, and realize the win-win of the adult colleges development and the rural women education. Finally, the remote education breaks the limit of time and space, and builds a freeway for women training. The remote education has large developing space and potential. Using convenient and efficient network technique, the remote education may convey the training of practical technology and the skills of experts to each household. The women may obtain high-quality educational resources without leaving home. This meets the women's demand of training at a low cost, and paves the way of the advanced technology extension. However, it is necessary to note that presently there are lots of deficiencies in rural remote education such as high-quality network educational resources scarce, the construction of broadband networks serious lagging in the vast rural China and the cost of cellphone traffic expensive [17].

Thirdly, the rural talents selection mechanism should be improved and the vision for selecting talents should be widened. It should be vigorously promoted that one person works as both the secretary of village party organization and the head of the village neighborhood committee. It should be enlarged further that the members of the Village Party Branch and the members of the Village Committee cross-hold posts, thus realizing reducing staff and improving efficiency. One rural able-person may activate a village, hence the talents selection should not stick to an individual pattern. (i) The talents selecting in the village. The masses should be guaranteed the rights to be informed, participate, vote and supervise in selecting and using talents. The masses should be preached the party policy and selection standard of cadre, be announced the selecting position and its prerequisite, and be leaded to participate in candidate nomination, which may ensure grass-roots cadres coming from the masses. (ii) The government department appointing. For a few "feeble, weak, disorderly and poor" villages with complicated patriarchal clan factionalism and more contradictions, if there are not suitable candidates in the villages, the government functionaries and public institution staff from the county units should be transferred to the villages, because they are devoted and with high political ideological quality, and familiar with 
the rural work. (iii) Recruiting through public selection and test. The counties should be allowed to recruit college graduates holding the post of village cadres through public channels, improving the structures of village cadres. (iv) Society recruiting and selecting. The returned youth, veterans, and migrant employees and businessmen with knowledge and specialties should be allowed to compete for the village cadres [18].

\section{Acknowledgements}

The study was supported by the HSSGP of Education Department of Hubei Province - 'the investing performance of farmland water conservancy and government intervention effect', the HGNU-DPEF Consulting Project-'the Huangzhou Dongsheng Plumbing Equipment Firm Participating in the Supply of Huanggang Rural Farmland Water Conservancy', and the HGNU TDPBBP_-'teaching reform and innovation of 'Econometrics' of economic class in application oriented university'.

\section{References}

[1] X. Wang, and Q. Lu, "The property rights arrangement and the peasant households' investing willing: Comparative analysis of three management and maintenance patterns of small scale water conservation facilities," Journal of Agro-Forestry Economics and Management, vol. 14, pp. 259-266. (In Chinese)

[2] J. Hill, "The role of authority in the collective management of hill irrigation systems in the Alai (Kyrgyzstan) and Pamir (Tajikistan)," Mountain Research and Development, vol. 33, pp. 294-304.

[3] D. A. Zema, A. Nicotra, V. Tamburino, and S. M. Zimbone, "Performance assessment of collective irrigation in water users' associations of Calabria (southern Italy)," Irrigation and Drainage, vol. 64, pp. 314-325.

[4] W. Ghazouani, S. Marlet, I. Mekki, L. W. Harrington, and A. "Vidal, Farmers' practices and community management of irrigation: why do they not match in Fatnassa Oasis," Irrigation and Drainage, vol. 61, pp. 39-51.

[5] N. Singh, and O. P. Singh, "Climate change, water and gender: Impact and adaptation in North-Eastern Hills of India," International Social Work, vol. 58, pp. 375-384.
[6] Y. Lv, "Study on the market operation of management and maintenance of the small-scale irrigation works in Dingtao County,” China Water Resources, 2015, pp. 50-51. (In Chinese)

[7] Y.-c. Qu, "The public character draining and governing of the market-oriented provision of the rural public goods," Chinese Public Administration, 2014, pp. 73-76. (In Chinese)

[8] P.-q. Ma, "The policy evaluation of the farmland water conservation marketization," Rural Economy, 2014, pp. 107-110. (In Chinese)

[9] A. Banerji, J. V. Meenakshi, and G. Khanna, "Social contracts, markets and efficiency: Groundwater irrigation in North India," Journal of Development Economics, vol. 98, pp. 228-237.

[10] T.-x. Tan, "The worries of the familial provision of the farmland water conservation- Take the case of a town on the Jianghan Plain,” Gansu Social Sciences, 2006, pp. 219-221. (In Chinese)

[11] S.-y. Wang, "Three farmland irrigation patterns and the Jianghan Plain drought — Study on the agricultural risk under the noncooperation view," Gansu Social Sciences, 2006, pp. 217-219. (In Chinese)

[12] M. Latif, Z. U. Haq, and G. Nabi, "Comparison of state-managed and farmer-managed irrigation systems in Punjab, Pakistan," Irrigation and Drainage, vol. 63, pp. 628-639.

[13] P. Das, "Women's participation in community-level water governance in urban India: The gap between motivation and ability,” World Development, vol. 64, pp. 206-218.

[14] L.-x. Guo, B. Zhang, Sh.-p. Dai, and Y.-m. Wang, "Patterns of domestic water use in rural areas of Zhangye, China: Based on gender difference," 1st Conference on Environmental Pollution and Public Health. Wuhan, China, SEP 10-11, 2010.

[15] B. Agarwal, 2011. "Food Crisis and Gender Inequality," DESA Working Paper $\quad$ No. 107. http://www.un.org/esa/desa/papers/2011/wp107_2011.pdf.

[16] X.-q. Luo, "Why doesn't the water flow when the channel has been formed-Analysis of the difficulties of selling water of the Dabeiwan pump station," China Reform, 2006, pp. 72-75. (In Chinese)

[17] R.-h. Duan, "Study on the questions of the rural women education in the context of life-long education," Continue Education Research, 2015, pp. 41-44. (In Chinese)

[18] A. Zhang, "Study on the reform of the rural grass-roots cadres selecting patterns," Cadres Tribune, 2011, pp. 31-32. (In Chinese). 